\title{
Sodium monensin or propolis extract in the diet of crossbred $(1 / 2$ Red Angus vs. $1 / 2$ Nellore) bulls finished in feedlot: chemical composition and fatty acid profile of the Longissimus muscle
}

\section{Monensina sódica ou extrato de própolis em dietas de bovinos mestiços ( $1 \frac{1}{2}$ Red Angus vs. $1 / 2$ Nelore) terminados em confinamento: composição química e ácidos graxos do músculo Longissimus}

\author{
Maribel Velandia Valero'; Fernando Zawadzki²; Mônica Chaves Françozo ${ }^{3}$; \\ Mariana de Souza Farias; ; Polyana Pizzi Rotta5; Ivanor Nunes Prado ${ }^{6 *}$; Jesuí \\ Vergílio Visantainer ${ }^{7}$; Lúcia Maria Zeoula ${ }^{8}$
}

\begin{abstract}
This work was carried out to evaluate the chemical composition and the fatty acid profile of the Longissimus muscle of crossbred bulls (F1 - 1/2 Red Angus $x 1 / 2$ Nellore) with an initial average age of 20 months old and an initial average weight of $393 \pm 24 \mathrm{~kg}$ finished in feedlot. Three treatments (Control - CON, Sodium monensin - MON and Propolis extract - PRO) were evaluated. The animals were kept in feedlot for 70 days and slaughtered at an average weight of $498 \pm 25 \mathrm{~kg}$. They were fed with corn silage (roughage), cracked corn, soybean meal, urea, limestone and mineral salt. The roughage:concentrate ratio was 50:50. The bulls were fed twice daily, at 8 a.m. and 4 p.m. The chemical composition and the fatty acid profile of the Longissimus muscle was measured between the $12^{\text {th }}$ and $13^{\text {th }}$ ribs. The inclusion of additives (sodium monensin or propolis extract) did not influence $(\mathrm{P}>0.05)$ the chemical composition (moisture, crude protein, ashes, total lipids and total cholesterol) of the animals' Longissimus muscle. Therefore, diet has little effect on fatty acid composition of the Longissimus muscle of bulls. However, the percentage of C18:2 $\mathrm{n}-6$ fatty acid was lower $(\mathrm{P}<0.05)$ as a percentage of total fatty acids in the CON diet in comparison to the MON and PRO diets. On the contrary, the percentage of $\mathrm{C} 22: 6 n-3$ fatty acid was higher $(\mathrm{P}<0.05)$ as a percentage of total fatty acids in the CON diet in comparison to the PRO diet. However, diet did not influence $(\mathrm{P}>0.05)$ polyunsaturated, monounsaturated, saturated fatty, $n-6$, or $n-3$ fatty acids or the ratio of PUFA/SFA and $n-6 / n-3$ fatty acids.
\end{abstract}

Key words: CLA, cholesterol, fatty acid, ionophores, meat quality

\section{Resumo}

Este trabalho foi realizado para estudar o efeito da adição de monensina sódica ou produto à base de própolis sobre as características de carcaça e composição química do músculo Longissimus de bovinos

\footnotetext{
1 Post-Graduate student. Department of Animal Science. State University of Maringá. E-mail: maribelvelandia@hotmail.com

2 Post-Graduate student. Department of Animal Science. State University of Maringá. E-mail: fernandozawadzki@hotmail.com

3 Post-Graduate student. Department of Animal Science. State University of Maringá. E-mail: monicacf.vet@hotmail.com

4 Post-Graduate student. Department of Animal Science. State University of Maringá. E-mail: marianafarias@gmail.com

5 Graduate student. Department of Animal Science. State University of Maringá. E-mail: polianazootecnia@hotmail.com

6 PhD, Prof. Department of Animal Science. State University of Maringá. Av. Colombo, 5790. CEP 87020-900. Maringá, Paraná, Brazil. Fellowship of CNPq IA. E-mail: inprado@uem.br

7 PhD, Prof. Department of Chemistry. State University of Maringá. E-mail: jesuiv@gmail.com

8 PhD, Prof. Department of Animal Science. State University of Maringá. Av. Colombo, 5790. CEP 87020-900. Maringá, Paraná, Brazil. Fellowship of CNPq. E-mail: lmzeoula@uem.br

*Corresponding author
} 
mestiços não castrados terminados em confinamento. Foram usados 24 bovinos com peso vivo médio de $393,3 \pm 24 \mathrm{~kg}$ e 20 meses de idade. Os bovinos foram divididos em três tratamentos: 1. Controle (CON), 2. Monensina sódica $(\mathrm{MON})$ ou 3. Produto à base de própolis (PRO). Os bovinos foram mantidos em confinamento durante 70 dias e alimentados com silagem de milho (volumoso) e milho moído, farelo de soja, ureia, calcário e sal mineral (concentrado). A relação volumoso: concentrado foi de 50:50. Os bovinos foram alimentados duas vezes ao dia (8 e 16 horas). Foram determinadas as características de carcaça e composição química do músculo Longissimus. As características quantitativas (peso de carcaça quente, rendimento de carcaça quente, espessura de gordura de cobertura, área de olho de lombo e a percentagem de músculo, gordura e osso) e qualitativas (marmorização, textura e cor) das carcaças não foram alteradas $(\mathrm{P}>0,05)$ pelas dietas. A composição química do músculo Longissimus (umidade, cinzas, proteína bruta, lipídeos totais e colesterol total) foi semelhante $(\mathrm{P}>0,05)$ nos bovinos das três dietas. Da mesma forma, a composição de ácidos graxos saturados, monoinsaturados, poliinsaturados, $n$-6 e $n-3$ não foram alterados $(\mathrm{P}>0,05)$ pelas dietas, assim como as razões AGPI/AGS e $n-6 / n-3$.

Palavras-chave: CLA, colesterol, ácidos graxos, ionóforos, qualidade da carne

\section{Introduction}

To increase animal production, it is necessary to develop new processes and technologies. Additives (ionophores) are used in ruminant feed with the purpose of improving alimentary efficiency (OLIVEIRA et al., 2006). The use of sodium monensin, a polyether antibiotic, is one of the most common methods for modulating ruminal fermentation (DUFFIELD; BAGG, 2000). When used in ruminant diets, sodium monensin acts on gram-positive bacteria by altering the flux of ions in the cellular membrane to select gramnegative bacteria (DUFFIELD; BAGG, 2000). The primary action of the monensin appears to take place in the rumen. Monensin's modes of action rely on the selective growth inhibition of gram-positive bacteria (VAN NEVEL; DEMEYER, 1988), reducing lactic acid production (DENNIS; NAGARAJA; BARTLEY, 1981) and methanogenesis in the rumen (GOODRICH et al., 1984) and increasing the molar proportion of propionate (GOODRICH et al., 1984) and N retention. The positive production responses of livestock to dietary monensin supplementation have been well-documented, e.g., the improvement of feed conversion, particularly in high-grain diets (BOUCQUÉ et al., 1982; OLIVEIRA et al., 2006).

Monensin inhibits lipolysis and, to some extent, fatty acid biohydrogenation (VAN NEVEL;
DEMEYER, 1995), so it may also affect the production of fatty acids in the rumen. However, Köhler, Karch and Schmidt (2000) reported that certain antibacterials used as growth promoters in animal feeding might increase the horizontal transfer of virulence genes between bacteria, though the effect was not observed in monensin in vitro. The use of in-feed antibiotics is subject to critique and raises concerns because of its potential involvement in the presence of antibiotic residues in animal products and the development of antibiotic-resistant pathogenic microbes. In Europe, the inclusion of sodium monensin in ruminant diets is prohibited (EPC, 2003). New research is thus necessary for the development of alternative products for ruminant diets, and antimicrobial feed additives must be replaced by specific feed additives (MARTIN et al., 1999).

Propolis has several demonstrated bioactivities, especially antibacterial action related to flavonoids (MARCUCCI, 1995). However, studies of the effect of propolis extract on meat quality in cattle are not present in the literature.

The present study was carried out to investigate the chemical composition and the fatty acid profile of the Longissimus muscle of $1 / 2$ Red Angus $x$ $1 / 2$ Nellore bulls finished in feedlot and fed with sodium monensin or propolis extract. 


\section{Material and Methods}

\section{Animal management and sampling}

The committee of Animal Production at the State University of Maringá approved this study, which was carried out at the Experimental Farm of the State University of Maringá, Paraná, Southern Brazil, and followed the guiding principles of biomedical research with animals (CIOMS, 1985). The analyses of diets were performed at the Laboratory of Feed Analyses and Animal Nutrition at the State University of Maringá.

Thirty-three bulls ( $1 / 2 \operatorname{Red}$ Angus $x 1 / 2$ Nellore) at an initial average age of 20 months and an initial average live weight of $394 \mathrm{~kg} \pm 24.0$ were used. Before the experiment, the bulls were kept in pasture (Brachiaria decumbens) without supplementation.

The bulls were weighed at the beginning of the experiment. Thereafter, they were weighed every 28 days after observing a 16-hour fast, which was accomplished by removing all feed at 4 p.m. the day prior to weighing. The total experimental period lasted 70 days, during which the animals reached an average final live weight of $499 \pm 24.9 \mathrm{~kg}$.

The bulls were kept in separate, individual pens (10 $\mathrm{m}^{2}$ for each animal) and fed twice daily. The bulls had access to a diet formulated to meet requirements for the fattening of beef cattle (NRC, 1996) at a gain of $1.50 \mathrm{~kg} /$ day. They were fed with $50 \%$ corn silage, $43.2 \%$ cracked corn, $5.41 \%$ soybean meal, $0.47 \%$ urea, $0.47 \%$ limestone and $0.47 \%$ mineral salt (Table 1$)$. The dry matter (DM), crude protein $(\mathrm{CP})$, organic matter $(\mathrm{OM})$, mineral matter (MM), extract ether (EE) and neutral fiber detergent (NFD) were determined using the method described by AOAC (1998).

Table 1. Chemical composition of the ingredients and basal diet and percent composition (\%/DM) of the diet.

\begin{tabular}{|c|c|c|c|c|c|c|c|c|c|}
\hline \multirow[b]{2}{*}{ Ingredients } & \multirow[b]{2}{*}{ DM $^{1}$} & \multicolumn{7}{|c|}{$\%$ DM } & \multirow[b]{2}{*}{ Diet \% } \\
\hline & & $\mathbf{C P}^{2}$ & $\mathbf{O M}^{3}$ & $\mathbf{E E}^{4}$ & $\mathrm{NDF}^{5}$ & $\mathrm{ADF}^{6}$ & $\mathbf{T C}^{7}$ & $\mathrm{NFC}^{8}$ & \\
\hline Corn silage & 32.1 & 8.15 & 96.5 & 2.06 & 48.4 & 25.6 & 86.3 & 38.0 & 52.0 \\
\hline Corn cracked & 88.9 & 8.93 & 99.1 & 3.50 & 17.7 & 4.40 & 86.6 & 68.9 & 42.9 \\
\hline Soybean meal & 88.6 & 49.0 & 93.7 & 1.30 & 13.7 & 5.97 & 43.5 & 29.8 & 4.30 \\
\hline Mineral salt & 99.3 & & & & & & & & 0.32 \\
\hline Limestone & 99.3 & & & & & & & & 0.19 \\
\hline Urea & 97.5 & 282 & & & & & & & 0.32 \\
\hline Diet & 41.9 & 11.1 & 97.1 & 2.62 & 33.3 & 15.4 & 83.9 & 50.6 & 100 \\
\hline
\end{tabular}

${ }^{1}$ dry matter, ${ }^{2}$ crude protein, ${ }^{3}$ organic matter, ${ }^{4}$ ether extract, ${ }^{5}$ neutral detergent fiber, ${ }^{6}$ acid detergent fiber, ${ }^{7}$ total carbohydrates, ${ }^{8}$ non carbohydrates fiber.

Three treatments were used in this study: CON - control (8 bulls), MON - sodium monensin (8 bulls) and PRO - propolis extract (7 bulls). The propolis extract LLOS $(\mathrm{C} 1++)$ was prepared according to Franco e Bueno (1999). Extracts with alcohol were diluted between 50 to $96^{\circ} \mathrm{GL}$ with a fixed concentration of propolis extract. The extracts were dried using lyophilization during 24 hours. The samples were stored in closed bottles at a temperature of $-5^{\circ} \mathrm{C}$ (this method was chartered under intellectual property number PI 0605768$3)$. To prepare the concentrates, the extracts were 
established at an ambient temperature and mixed with soybean and corn to form an additive used to provide the concentrate to the animals. The product LLOSC $1++$ contains $0.054 \mathrm{mg} / \mathrm{g}$ of total flavonoids in chrysin. Monensin is produced by Elanco®.

At the same time, monensin and propolis extract nucleus were mixed with concentrate to feed the animals (300 mg/animal/day of monensin and $35 \mathrm{~g} /$ animal/day of propolis extract nucleus).

\section{Chemical composition}

The animals were slaughtered at a commercial slaughterhouse $20 \mathrm{~km}$ away from the Maringá city according to Brazilian industrial practices. Following slaughter, the carcasses were identified and chilled for $24 \mathrm{~h}$ at $4^{\circ} \mathrm{C}$. After chilling, the appropriate section of the carcass was used to determine quantitative characteristics. Twenty-four hours later, Longissimus muscle (LM) samples were taken by a complete cross-section between the $12^{\text {th }}$ and $13^{\text {th }}$ ribs. The fat thickness was discarded, and the muscle was frozen at $-20^{\circ} \mathrm{C}$ for further analysis.

The samples were thawed at room temperature $\left(20^{\circ} \mathrm{C}\right)$, grounded (cracker mill), homogenized and analyzed in triplicate.

Meat moisture and ash percentage were determined according AOAC (CUNNIF, 1998). Crude protein percentage was obtained by the Kjeldahl method (CUNNIF, 1998). Total lipids were extracted through the Bligh and Dyer method (1959) using a chloroform/methanol mixture. Fatty acid methyl esters (FAME) were prepared by triacylglycerol methylation, according ISO method (1978).

\section{Cholesterol quantification}

Cholesterol analysis was carried out by method modified by Rowe et al. (1999). A 60\% (w/v) solution of potassium hydroxide was added to the samples in quantities equivalent to $2 \mathrm{~mL} \mathrm{~h}^{-1}$ of sample under 1-h reflux. The residue was dissolved again in $2 \mathrm{~mL}$ hexane containing $0.2 \mathrm{mg} \mathrm{mL}^{-1} 5-\alpha$ cholestane internal standard (IS) (Sigma, USA).

Cholesterol content was analyzed in 14-A gas chromatograph (Shimadzu, Japan), equipped with a flame ionization detector and a fused silica capillary column (25 m long, 0.25-mm internal diameter and $0.20 \mu \mathrm{m}$ Ohio Valley-30). The injector, column and detector temperatures were 260,280 and $280^{\circ} \mathrm{C}$, respectively. Ultra-pure gas fluxes (White Martins) were used in the following quantities: $1.5 \mathrm{~mL} \mathrm{~min}^{-1}$ $\mathrm{H}_{2}$ as carrier gas, $30 \mathrm{~mL} \mathrm{~min}^{-1} \mathrm{~N}_{2}$ as make-up gas, $300 \mathrm{~mL} \mathrm{~min}{ }^{-1}$ as synthetic gas and $30 \mathrm{~mL} \mathrm{~min}^{-1} \mathrm{~N}_{2}$ for the flame. The sample injection split mode was: $1: 150$. Peak integration was carried out with a CG300 computing integrator (CG Instruments, Brazil), and cholesterol was identified by comparison with standards from Sigma (USA). Sample cholesterol quantification was carried out after verification of linearity method. Standard cholesterol solutions (Sigma, USA) were prepared with concentrations $0.0,0.4,0.8,1.6$ and $2.0 \mathrm{mg} \mathrm{mL}^{-1}$, all containing $0.20 \mathrm{mg} \mathrm{mL}^{-1} 5 \alpha$-cholestane (Sigma, USA); the solutions were then analyzed. The ratio of the areas of cholesterol and 5- $\alpha$ cholestane was plotted against the cholesterol concentration for injected volumes of $0.0,2.0,3.0,4.0$ and $5.0 \mu \mathrm{L}$. The curve obtained was used for cholesterol analysis in $\mathrm{mg} 100 \mathrm{~g}^{-1}$.

\section{Analysis of fatty acid methyl esters}

The fatty acids methyl esters (FAMEs) were analyzed in gas chromatograph (Varian, USA) equipped with a flame ionization detector and fused silica capillary column CP-7420 (100 m, 0.25 $\mathrm{mm}$ and $0.39 \mu \mathrm{m}$ o.d., Varian, USA Select Fame). Column temperature was programmed at $165^{\circ} \mathrm{C}$ for $18 \mathrm{~min}, 180^{\circ} \mathrm{C}\left(30^{\circ} \mathrm{C} \mathrm{m^{-1 }}\right)$ for $22 \mathrm{~min}$ and $240^{\circ} \mathrm{C}$ $\left(15^{\circ} \mathrm{C} \mathrm{m^{-1 }}\right)$ for $30 \mathrm{~min}$, with 45 -psi pressure. The injector and detector were kept at $220 \mathrm{oC}$ and $245^{\circ} \mathrm{C}$, respectively. The gas fluxes (White Martins) used were $1.4 \mathrm{~mL} \mathrm{~min}^{-1}$ for the carrier gas $\left(\mathrm{H}_{2}\right), 30 \mathrm{ml}$ $\mathrm{min}^{-1}$ for the make-up gas (N2), $30 \mathrm{~mL} \mathrm{~min}^{-1}$ for $\mathrm{H}_{2}$ 
and $300 \mathrm{ml} \mathrm{min}{ }^{-1}$ the synthetic flame gas. Sample injection split mode was $1 / 80$. Fatty acids were identified by comparing the relative retention times of the samples' FAME peaks with fatty acids methyl esters standards from Sigma (USA). The samples were spiked with the standard. The peak areas were determined with Star software (Varian). The data were expressed as percentages of the normalized area of fatty acids.

The peak areas were determined by Data Station Advanced DataApex Clarity Litr. Software (v.2.4.1.9.1, 2003) and the identification of total cholesterol was effectuated by comparison with Sigma (USA).

\section{Experimental design and statistical analysis}

The experimental design consisted of three treatments: CON (control), MON (sodium monensin) and PRO (propolis extract). The data were submitted to variance analysis and the means were compared using a Tukey test performed with SAS statistical software (2000).

\section{Results and Discussion}

\section{Chemical composition}

The presence of additives (sodium monensin and propolis extract) did not influence $(\mathrm{P}>0.05)$ the chemical composition (moisture, ash, crude protein, total lipids and total cholesterol) of the Longissimus muscle of crossbred bulls finished in feedlot (Table 2).

Table 2. Chemical composition (means) of the Longissimus muscle of $1 / 2$ Red Angus $x$ Nellore bulls finished in feedlot.

\begin{tabular}{lccccc}
\hline & \multicolumn{3}{c}{ Diets } & & \\
\cline { 2 - 4 } Items & $\mathbf{C O N}$ & $\mathbf{M O N}^{2}$ & $\mathbf{P R O}^{3}$ & $\mathbf{S E}^{\mathbf{4}}$ & $\mathbf{P}<\mathbf{F}$ \\
\hline $\mathbf{n}$ & $\mathbf{8}$ & $\mathbf{8}$ & $\mathbf{8}$ & & $\mathrm{NS}$ \\
\hline Moisture, \% & 74.6 & 74.8 & 74.4 & 0.87 & $\mathrm{NS}$ \\
Ash, \% & 1.06 & 1.06 & 1.05 & 0.02 & $\mathrm{NS}$ \\
Crude protein, \% & 22.9 & 21.8 & 22.8 & 0.25 & $\mathrm{NS}$ \\
Total lipids, \% & 1.60 & 1.45 & 1.65 & 0.09 & $\mathrm{NS}$ \\
Total cholesterol $^{5}$ & 36.8 & 36.4 & 37.4 & 0.32 & \\
\hline
\end{tabular}

${ }^{1}$ control, ${ }^{2}$ sodium monensin, ${ }^{3}$ propolis extract, ${ }^{4}$ standart error, ${ }^{5} \mathrm{mg} / 100 \mathrm{~g}$ of muscle, NS - non significant.

The percentage of moisture of the Longissimus muscle $(74.6 \%)$ is near to the values observed in bulls finished in feedlot conditions (KAZAMA et al., 2008; ROTTA et al., 2009a; 2009b). Moisture percentage depends of total lipids of the Longissimus muscle because fat is poor in water.

Similarly, ash percentage $(1.06 \%)$ of the Longissimus muscle resembles results obtained by some authors (PRADO et al., 2008b; 2008c; 2008d; DUCATTI et al., 2009; PRADO et al., 2009a; 2009b; 2009c). Ash percentage changes little as a result of the presence of additives.

The percentage of crude protein of the Longissimus muscle $(22.7 \%)$ is similar to some studies that used bulls finished in feedlot (PRADO et al., 2008b; 2008c; 2008d). In general, crude protein percentage varies little due to diet. 
Total lipid percentage $(1.56 \%)$ is considered low in comparison to bulls finished in feedlot that received high energy diets. This could be explained by the animals' age (24 months), breed ( $1 / 2$ Red Angus x 1/2 Nellore) and physiological condition (bulls). In general, animals slaughtered at younger age show less total lipid percentage in the Longissimus muscle (PADRE et al., 2006; PADRE et al., 2007; MACEDO et al., 2008; ROTTA et al., 2009b). Similarly, bulls crossbred from the zebu breed show low percentage of total lipids of the Longissimus muscle as a function of lesser selection of this characteristic (PRADO et al., 2008c). Accordingly, bulls finished in feedlot show less total lipid percentage as a function of hormonal effects (testosterone) that act to high deposition of muscle tissue (LEE et al., 1990).

The total average cholesterol for the treatments was $36.8 \mathrm{mg} / 100 \mathrm{~g}$ of muscle. These total cholesterol levels can be related to the age of slaughter (24 months) and the breed of the animals ( $1 / 2$ Red Angus $x 1 / 2$ Nellore). In general, animals slaughtered at an age of 24 months or less show variation between 30.0 to $45.0 \mathrm{mg} / 100 \mathrm{~g}$ of muscle (PRADO et al., 2009a; 2009b; ROTTA et al., 2009b).

\section{Fatty acid profile}

The fatty acid percentage in LM intramuscular fat is shown in Table 3. Fatty acid diversity is partly explained by the biohydrogenation that occurs in the rumen (TAMMINGA; DOREAU, 1991).

Diet has little effect on the fatty acid composition of the Longissimus muscle of bulls. The percentage of C18:2 n-6 fatty acid was similar $(\mathrm{P}>0.05)$ between the MON $(6.32 \%)$ and PRO $(6.28 \%)$ diets and superior $(\mathrm{P}<0.05 \%)$ to the PRO diets (4.94\%). However, the CON diet presented a higher $(\mathrm{P}<0.05)$ percentage of $\mathrm{C} 18: 6$ $n-3$ fatty acid $(2.18 \%)$ in comparison to the PRO $\operatorname{diet}(1.42 \%)$.

Due ruminant diets contain a low fat concentration, the majority of the adipose tissue is synthesized from lipogenesis. The ionophore sodium monensin inhibits lipolysis and to some extent unsaturated fatty acid biohydrogenation (VAN NEVEL; DEMEYER, 1995), so monensin may also affect the production of fatty acids in the rumen. Fatty acids are elongated up to $\mathrm{C} 18: 0$ and are converted into $\mathrm{C} 18: 1$ by unsaturation (RULE; MACNEIL; SHORT, 1997). As the adipose tissue increases, the deposition of $\mathrm{C} 18: 1$ content also increases and C18:2 is reduced. The effects of nutrition on meat quality are more significant in terms of carcass characteristics and chemical composition (ABRAHÃO et al., 2005; PRADO et al., 2008a; MAGGIONI et al., 2009; ROTTA et al., 2009b). On the other hand, the effects of nutrition on fatty profile are generally small but significant; they are often very important in terms of nutritive value, color of the product and quality or fat consistency (WEBB; O’NEIL, 2008).

The additives (sodium monensin or propolis extract) did not alter $(\mathrm{P}>0.05)$ to saturated (SFA), monounsaturated (MUFA) and polyunsaturated (PUFA) fatty acids on Longissimus muscle of bulls finished in feedlot. The majority of fatty acids found on Longissimus muscle were SFA (44.8\%), followed by MUFA (42.7\%) and PUFA (12.5\%). Likewise, Aricetti et al. (2008) and Prado et al. (2008a; 2008b) observed similar percentages of SFA, MUFA and PUFA in bulls finished under similar diets and handling conditions as in this experiment. Thus, SFA, MUFA and PUFA fatty acids percentages vary little as a function of diet.

The percentage of $n-3$ fatty acids was low in comparison with $n-6$. This was because the predominant polyunsaturated fatty acid in meat is C18:2 n-6, which appears in high concentration in comparison with $\mathrm{C} 18: 3 n-3$. 
Table 3. Fatty acid profile (means) of the Longissimus muscle of $1 / 2$ Red Angus $x \frac{1}{2}$ Nellore bulls finished in feedlot.

\begin{tabular}{|c|c|c|c|c|c|}
\hline \multirow[t]{2}{*}{ Fatty acids } & \multicolumn{3}{|c|}{ Diets } & \multirow[b]{2}{*}{$\mathbf{S E}^{4}$} & \multirow[b]{2}{*}{$\mathbf{P}<\mathbf{F}$} \\
\hline & $\mathrm{CON}^{1}$ & $\mathrm{MON}^{2}$ & $\mathbf{P R O}^{3}$ & & \\
\hline n & 8 & 8 & 8 & & \\
\hline 14:0 & 1.99 & 2.06 & 1.87 & 0.14 & NS \\
\hline $14: 1 n-7$ & 0.17 & 0.19 & 0.20 & 0.02 & NS \\
\hline $15: 0$ & 0.31 & 0.28 & 0.31 & 0.05 & NS \\
\hline $16: 0$ & 25.4 & 25.9 & 25.4 & 0.55 & NS \\
\hline $16: 1 n-9$ & 0.22 & 0.20 & 0.24 & 0.02 & NS \\
\hline $16: 1 n-7$ & 2.64 & 2.57 & 2.57 & 0.14 & NS \\
\hline $17: 0$ & 0.98 & 0.92 & 0.85 & 0.05 & NS \\
\hline $17: 1 n-9$ & 0.65 & 0.69 & 0.59 & 0.04 & NS \\
\hline 18:0 & 16.5 & 16.0 & 16.2 & 0.65 & NS \\
\hline $18: 1 n-9$ & 38.6 & 37.7 & 38.8 & 0.70 & NS \\
\hline $18: 1 n-7$ & 0.65 & 0.60 & 0.65 & 0.04 & NS \\
\hline $18: 2 n-6$ & $4.94 b$ & $6.32 \mathrm{a}$ & $6.28 \mathrm{a}$ & 0.42 & 0.05 \\
\hline 18:2 cis 9, trans 11 & 0.16 & 0.16 & 0.17 & 0.01 & NS \\
\hline $18: 3 n-6$ & 0.72 & 0.75 & 0.78 & 0.06 & NS \\
\hline $18: 3 n-3$ & 0.21 & 0.17 & 0.17 & 0.02 & NS \\
\hline 20:0 & 0.19 & 0.17 & 0.20 & 0.02 & NS \\
\hline $20: 4 n-6$ & 1.53 & 1.63 & 1.54 & 0.16 & NS \\
\hline $20: 5 n-3$ (EPA) & 1.01 & 1.10 & 1.22 & 0.11 & NS \\
\hline $22: 4 n-6$ & 0.72 & 0.59 & 0.82 & 0.09 & NS \\
\hline 22:6 n-3 (DHA) & $2.18 \mathrm{a}$ & $1.73 \mathrm{ab}$ & $1.42 b$ & 0.17 & 0.01 \\
\hline PUFA & 13.1 & 12.4 & 11.9 & 1.33 & NS \\
\hline MUFA & 42.5 & 42.3 & 43.3 & 0.89 & NS \\
\hline SFA & 44.4 & 45.2 & 44.8 & 0.78 & NS \\
\hline$n-6$ & 8.68 & 8.69 & 8.10 & 1.07 & NS \\
\hline$n-3$ & 4.00 & 3.42 & 3.12 & 0.36 & NS \\
\hline PUFA/SFA & 0.30 & 0.28 & 0.27 & 0.04 & NS \\
\hline$n-6 / n-3$ & 2.64 & 3.16 & 3.21 & 0.22 & NS \\
\hline
\end{tabular}

${ }^{1}$ control, ${ }^{2}$ sodium monensin, ${ }^{3}$ propolis extract, ${ }^{4}$ standart error, NS - non significant, means followed by the different letters differ by Tukey test.

The PUFA/SFA ratio was low for all diets (0.28). higher for this ratio (ENGLAND, 1994). The ideal Thus, no diet had recommended values of 0.4 or PUFA/SFA ratio plays an important role in reducing 
the risk of coronary heart disease; however, the optimal balance between these two classes of fatty acids is still a matter of debate (HU, 2001).

No difference $(\mathrm{P}>0.10)$ was observed for the $n-6 / n-3$ ratio among different diets. This ratio must be less than 4.0 (ENGLAND, 1994). In this study, the average found for $n-6 / n-3$ was 3.0, a value lower than that recommended by the English Department of Health (ENGLAND, 1994).

\section{Conclusions}

The addition of sodium monensin or propolis extract did not alter the chemical composition of the Longissimus muscle of bulls finished in feedlot. However, the fatty acid profile was changed by the addition of sodium monensin or propolis extract in the diets. In consideration of the prohibition of monensin sodium in animal feed, propolis extract could provide an alternative because it did not damage meat quality in comparison with the control treatment, and it could help reduce the greenhouse effect.

\section{References}

ABRAHÃO, J. J. S.; PRADO, I. N.; PEROTTO, D.; MOLETTA, J. L. Effects of replacing corn with increasing levels of cassava starch by-products on carcass characteristics and meat for young bulls. Brazilian Journal of Animal Science, Viçosa, v. 34, n. 5, p. 16401650, 2005.

AOAC. Official methods of analysis of AOAC International. $6^{\text {th }}$ ed. Arlington: Association of Official Analytical Chemists, 1998.

ARICETTI, J. A.; ROTTA, P. P.; PRADO, R. M.; PEROTTO, D.; MOLETTA, J. L.; MATSUSHITA, M.; PRADO, I. N. Carcass characteristics, chemical composition and fatty acid profile of Longissimus muscle of bulls and steers finished in a pasture system. Asian Australasian Journal of Animal Science, Seoul, v. 21, n. 10, p. 1441-1448. 2008.

BLIGH, E. G.; DYER, W. J. A rapid method of total lipid extraction and purification. Canadian Journal Biochemistry and Physiology, Ottawa, v. 37, n. 8, p. 911917, 1959.
BOUCQUÉ, C. H. V.; FIEMS, L. O.; COTTYN, B. G.; CASTTELS, M.; BUYSSE, F. X. Monensin-sodium as a performance-promoting additive for fattening bulls and its impact on carcass and meat quality characteristics. Animal Feed Science and Technology. Amsterdam, v. 7, n. 4, p. 401-410, 1982.

CIOMS/OMS. Council for International Organizations of Medical Services. WHO distribution and sales service, 1211 Geneva 27, Switzerland, International Guiding Principles for Biomedical Research Involving Animals, 1985.

CUNNIF, P. A. Official methods of analysis of AOAC international. $6^{\text {th }}$ ed. Arlington: Association of Official Analytical Chemists, 1998.

DENNIS, S. M.; NAGARAJA, T. G.; BARTLEY, E. E. Effects of lasalocid or monensin on lactate producing or using rumen bacteria. Journal of Animal Science, Savoy, v. 52 , n. 2, p. 418-426, 1981.

DUCATTI, T.; PRADO, I. N.;ROTTA, P. P.; PRADO, R. M.; PEROTTO, D.; MAGGIONI, D; VISENTAINER, J. V. Chemical composition and fatty acid profile in crossbred (Bos taurus $x$ Bos indicus) young bulls finished in feedlot. Asian-Australasian Journal Animal Science, Seoul, v. 22, n. 3, p. 433-439, 2009.

DUFFIELD, F. T.; BAGG, R. N. Use of ionophores in lactating dairy cattle: a review. Canadian Veterinary Journal, Ottawa, v. 41, n. 5, p. 388-394, 2000.

ENGLAND. Department of Health. Nutritional aspects of cardiovascular disease. London: HMSO, 1994. p. 3746. (Report on Health and Social Subjects, 46).

EUROPEAN PARLIAMENT AND OF THE COUNCIL - EPC. Regulation (EC) No 1831/2003 of 22 September 2003 on additives for use in animal nutrition. Official Journal of the European Union. Luxembourg, 18.10.2003, p. 253-262.

FRANCO, S. L.; BUENO, J. H. F. Otimização de processo extrativo de própolis. Infarma, Londrina, v. 11, n. 11/12, p. 48-51. 1999.

GOODRICH，R. D.; GARRETT, J. E.; GAST, D. R.; KIRICK, M. A.; LARSON, D. A.; MEISKE, J. C. Influence of monensin on the performance of cattle. Journal Animal Science, Savoy, v. 58, n. 6, p. 1484-1498, 1984.

INTERNATIONAL ORGANIZATION FOR STANDARDIZATION - ISO. Animal and vegetable fats and oils - preparation of methyl esters of fatty acids, ISO 5509. Geneva, 1978. p. 01-06.

KAZAMA, R.; ZEOULA, L. M.; PRADO, I. N.; SILVA, D. C.; DUCATTI, T.; MATSUSHITA, M. Quantitative 
and qualitative carcass characteristics of heifers fed different energy sources on a cottonseed hulls and soybean hulls based diet. Brazilian Journal of Animal Science, Viçosa, v. 37, n. 2, p. 350-357, 2008.

KÖHLER, B.; KARCH, H.; SCHMIDT, K. Antibacterial that are used as growth promoters in animal husbandry can affect the release of Shiga-toxin-2-converting bacteriophages and Shia toxin 2 from Escherichia coli strains. Microbiology, Reading, v. 146, n. 5, p. 10851090, 2000.

LEE, C. Y.; HENRICKS, D. M.; SKELLEY, G. C.; GRIMES, L. W. Growth and hormonal response of intact and castrate male cattle to trenbolone acetate and estradiol. Journal of Animal Science, Savoy, v. 68, n. 9, p. 2682-2689, 1990.

MACEDO, L. M.; PRADO, I. M.; PRADO, J. M.; ROTTA, P. P.; PRADO, R. M.; SOUZA, N. E.; PRADO, I. N. Chemical composition and fatty acids profile of five carcass cuts of crossbred heifers finished in feedlot. Semina:Ciências Agrárias, Londrina, v. 29, n. 3, p. 599610, 2008.

MAGGIONI, D.; MARQUES, J. A.; PEROTTO, D.; ROTTA, P. P.; DUCATTI, T.; MATSUSHITA, M.; SILVA, R. R.; PRADO, I. N. Bermuda grass hay or sorghum silage with or without yeast addition on performance and carcass characteristics of crossbred young bulls finished in feedlot. Asian Australasian Journal of Animal Science, Seoul, v. 22, n. 2, p. 206-215, 2009.

MARCUCCI, M. C. Propolis chemical composition, biological properties and therapeutic activity. Apidologie, Les Ulis, v. 26, n. 2, p. 83-99, 1995.

MARTIN, S. A.; AL-KHALDI, S. F.; EVANS, J. D.; SUlLIVAN, H. M. Potential for manipulating gastrointestinal microflora: alternatives to antibiotics and ionophores? Recent research development. Microbiology, Reading, v. 3, n. 2, p. 441-454, 1999.

NATIONAL RESEARCH COUNCIL - NRC. Nutrient requirements of beef cattle. $6^{\text {th }}$ ed. Washington, D.C.: National Academy Press, 1996. 242 p.

OLIVEIRA, J. S.; QUEIROZ, A. C.; LANA, R. P.; MANTOVANI, H. C.; GENEROSO, R. A. R. Effects of monensin and bee propolis on in vitro fermentation of amino acids by mixed ruminal bacteria. Brazilian Journal of Animal Science, Viçosa, v. 35, n. 1, p. 275281, 2006.

PADRE, R. G.; ARICETTI, J. A.; GOMES, S. T. M.; GOES, R. H. T. B.; MOREIRA, F. B.; PRADO, I. N.; VISENTAINER, J. V.; SOUZA, N. E.; MATSUSHITA, M. Analysis of fatty acids in Longissimus muscle of steers of different genetic breeds finished in pasture systems. Livestock Science, Amsterdam, v. 110, n. 1, p. 57-63, 2007.

PADRE, R. G.; ARICETTI, J. A.; MOREIRA, F. B.; MIZUBUTI, I. Y.; PRADO, I. N.; VISENTAINER, J. V.; SOUZA, N. E.; MATSUSHITA, M. Fatty acids profile and chemical composition of Longissimus muscle of bovine steers and bulls finished in pasture system. Meat Science, Amsterdam, v. 74, n. 1, p. 242-248, 2006.

PRADO, I. N.; ARICETTI, J. A.; ROTTA, P. P.; PRADO, R. M.; PEROTTO, D.; VISENTAINER, J. V.; MATSUSHITA, M. Carcass characteristics, chemical composition and fatty acid profile of the Longissimus muscle of bulls (Bos taurus indicus x Bos taurus taurus) finished in pasture systems. Asian Australasian Journal of Animal Science, Seoul, v. 21, n. 10, p. 1449-1457, 2008d.

PRADO, I. N.; ITO, R. H.; PRADO, J. M.; PRADO, I. M.; ROTTA, P. P.; MATSUSHITA, M.; VISENTAINER, J. V.; SILVA, R. R. The influence of dietary soyabean and linseed on the chemical composition and fatty acid profile of the Longissimus muscle of feedlot-finished bulls. Journal of Animal Feed Science, Jablonna, v. 17, n. 3, p. 307-317, 2008a.

PRADO, I. N.; OLIVEIRA, A. N.; ROTTA, P. P.; PEROTTO, D.; PRADO, R. M.; SILVA, R. R.; SOUZA, N. E.; MOLETTA, J. L. Chemical and fatty acid composition of Longissimus muscle of crossbred bulls finished in feedlot. Asian Australasian Journal of Animal Science, Seoul, v. 22, n. 7, p. 1054-1059, 2009c.

PRADO, I. N.; PRADO, R. M.; ROTTA, P. P.; VISENTAINER, J. V.; MOLETTA, J. L.; PEROTTO, D. Carcass characteristics and chemical composition of the Longissimus muscle of crossbred bulls (Bos taurus indicus vs Bos taurus taurus) finished in feedlot. Journal of Animal Feed Science, Jablonna, v. 17, n. 3, p. 295-306, 2008 b.

PRADO, I. N.; ROTTA, P. P.; PRADO, R. M.; VISENTAINER, J. V.; MOLETTA, J. L.; PEROTTO, D. Carcass characteristics and chemical composition of the Longissimus muscle of Purunã and $1 / 2$ Purunã x $1 / 2$ Canchin bulls. Asian Australasian Journal of Animal Science, Seoul, v. 21, n. 9, p. 1296-1302, 2008c.

PRADO, J. M.; PRADO, I. N.; VISENTAINER, J. V.; ROTTA, P. P.; PEROTTO, D.; MOLETTA, J. L.; PRADO, I. M.; DUCATTI, T. The effect of breed on chemical composition and fatty acid composition on Longissimus dorsi muscle of Brazilian beef cattle. Journal of Animal Feed Science, Jablonna, v. 18, n. 2, p. 231-240, 2009a.

PRADO, R. M.; PRADO, I. N.; MARQUES, J. A.; ROTTA, P. P.; VISENTAINER, J. V.; SILVA, R. R.; 
SOUZA, N. E. Meat quality of the Longissimus muscle of bulls and steers ( $1 / 2$ Nellore vs. $1 / 2$ Simenthal) finished in feedlot. Journal of Animal and Feed Science, Jablonna, v. 18, n. 2, p. 221-230, 2009b.

ROTTA, P.P.; PRADO, I. N.; PRADO, R. M.; MOLETTA, J. L.; SILVA, R. R.; PEROTTO, D. Carcass characteristics and chemical composition of the Longissimus muscle of Nellore, Caracu and Holstein-friesian bulls finished in feedlot. Asian Australasian Journal of Animal Science, Seoul, v. 22, n. 4, p. 598-604, 2009a.

ROTTA, P. P.; PRADO, R. M.; PRADO, I. N.; VALERO, M. V.; VISENATINER, J. V.; SILVA, R. R. The effects of genetic groups, nutrition, finishing systems and gender of Brazilian cattle on carcass characteristics and beef composition and appearance: a review. Asian Australasian Journal of Animal Science, Seoul, v. 22, n. 2, 1718-1734, 2009b.

ROWE, A.; MACEDO, F. A. F.; VISENTAINER, J. V.; SOUZA, N. E.; MATSUSHITA, M. Muscle composition and fatty acid profile in lambs fattened in dry-lot or pasture. Meat Science, Amsterdam, v. 51, n. 4, p. 283288, 1999.

RULE, D. C.; MACNEIL, M. D.; SHORT, R. E. Influence of sire growth potential, time on feed, and growing finishing strategy on cholesterol and fatty acids of ground carcass and Longissimus muscle of beef steers. Journal of Animal Science, Savoy, v. 75, n. 6, p. 1525-1533, 1997.

SAS Institute. SAS/STAT®. User's guide: statistics. Version 8.1. 4. ed. Cary: SAS Institute, 2000. v. 2.

TAMMINGA, S.; DOREAU, M. Lipids and rumen digestion. In: HOUANY, J. P. (Ed.). Rumen microbial metabolism and ruminant digestion. Paris: INRA, 1991. p. 151-164.

VAN NEVEL, C. J.; DEMEYER D. I. Manipulation of ruminal fermentation. In: HOBSON, P. N. (Ed.). The rumen microbial ecosystem. Essex: Elsevier, 1988. p. 387-443.

WEBB, E. C.; O’NEIL, H. A. The animal fat paradox and meat quality. Meat Science, Amsterdam, v. 80, n. 1, p. 28-36, 2008. 